\title{
Analysis of Planning for Clean Water Needs at Grand Sagara West Surabaya Hotel With the Green Buillding Concept
}

\author{
Sofyan Ali Rafsanjani*, F Edy Rooslan Santosa, Ronny Durrotun Nasihien \\ Department of Civil Engineering, Faculty of Engineering, Narotama University, Indonesia \\ *Corresponding author e-mail: sofyanhoyael@gmail.com
}

\begin{abstract}
Manuscript received 23 Feb 2021; revised 2 March. 2021; accepted 15 March 2021. Date of publication 2 April 2021

Water is the basic necessity of every living thing on earth. Humans depend on water not only for meeting domestic household needs but also for needs such as production needs, industrial needs and other needs. The need for clean water is the amount of water that will be used fairly for basic human needs (domestic) and other activities that require water. The hospitality industry is a commercially managed business. This study aims to determine the impact of the use of clean water that occurs during the construction and operation of the Grand Sagara West Surabaya Hotel on Tambak Wedi Village in the next 10 years. The need for clean water for Tambak Wedi Village in 2019 prior to the construction and operation of the Grand Sagara West Surabaya Hotel is $0.0566 \mathrm{~m}^{3} / \mathrm{sec}$, whereas after construction and operation in 2029 is $0.1118 \mathrm{~m}^{3} / \mathrm{sec}$. So, the amount of clean water discharge in Tambak Wedi Urban Village that must be fulfilled by the PDAM in Surabaya in 2029 is $0.0288 \mathrm{~m}^{3} / \mathrm{sec}$. Clean water, water needs, water discharge, hotel, PDAM Surabaya city.
\end{abstract}

Keywords: Clean Water, Water Needs, Water Discharge, Hoytel, PDAM Surabaya City.

\section{Introduction}

Water is a very important need for human survival, without water there would be no life on earth. Surabaya City as the capital of East Java Province is the largest city in Indonesia [1]. The city is located $796 \mathrm{~km}$ east of Jakarta, or $415 \mathrm{~km}$ northwest Denpasar, Bali. Based on preliminary data collection at the Grand Sagara West Surabaya Hotel, it is known that the hotel is a luxury hotel with various facilities and infrastructure available. With the various facilities available, of course the hotel uses quite a lot of clean water and waste water that is released to meet daily water needs [2].

Problem

1. What is the total clean water debit required for the Tambak Wedi Village area prior to the construction of the Hotel?

2. How manyClean water debit needed for the Tambak Wedi Kelurahan area after the construction and operation of the Hotel, as well as the need for water for the next 10 years projection?

3. What is the ratio of the use of clean water in Tambak Wedi Village before the construction of the Hotel and after the construction of the Hotel?

Aim

1. Knowing the total need for clean water debit needed for the Tambak Wedi Village area before the construction of the Grand Sagara West Suraaya Hotel.

2. Knowing the amount of clean water needed by the region Tambak Wedi Village after the construction and operation of Grand Sagara West Surabaya Hotel for now and the next 10 years projections. So that the results of this study can be used as the basis for PDAM Surabaya City to meet the needs of clean water in the Tambak Wedi Village [3] [4].

\section{Literature Review}

The following are several studies related to analysisplanning of clean water needs at the grand sagara west Surabaya hotel with the concept of green buillding.

a. Iwan Setiyanto 2017, Analysis of clean water needs (case study of Kutoarjo water intact installation), Muhammadyah University Purworejo. 
b. Ike Triani Eka Putri 2018, Analysis of clean water use in five star hotels (case study of Padma Bandung hotel), Pasundan University, Bandung.

c. Adlima Damayanti 2010, Analysis of domestic clean water needs in the village of Kedamin land and Kedamin village downstream, the State University of Islam Syarif Hidayatullah Jakarta.

d. Ika Kusumawati 2015,Analysis of clean water needs in the Nasik strait district of Kab. pickaxe prov. bangka belitung, Universitas Cikarang President.

Table 1. Daily Water Needs

\begin{tabular}{|c|c|c|c|c|c|}
\hline NO & Building Type & $\begin{array}{l}\text { Average daily } \\
\text { water use } \\
\text { (liters) }\end{array}$ & $\begin{array}{c}\text { Duration of } \\
\text { water use on } \\
\text { average a day } \\
\text { (hours) }\end{array}$ & $\begin{array}{l}\text { Comparison of } \\
\text { effective / total } \\
\text { floor area }(\%)\end{array}$ & Information \\
\hline 1 & Real estate & 250 & $8--10$ & $42-45$ & Every occupant \\
\hline 2 & Ordinary house & $160-250$ & $8--10$ & $50-53$ & Every occupant \\
\hline 3 & Apartment & $200-250$ & $8--10$ & $45-50$ & $\begin{array}{l}\text { Luxurious } 250 \mathrm{lt} . \\
\text { Intermediate } 180 \mathrm{lt} . \\
\text { Bachelors } 120 \mathrm{lt} .\end{array}$ \\
\hline 4 & Dormitory & 120 & 8 & & Bachelor \\
\hline 5 & Hospital & $\begin{array}{l}\text { Luxury> } 1000 \\
\text { Intermediate } \\
500-1000 \\
\text { General 350- } \\
500\end{array}$ & $8--10$ & $45-48$ & $\begin{array}{l}\text { (each patient bed) } \\
\text { Patient outside } 8 \text { lt. } \\
\text { Staff / employee } 120 \text { lt. } \\
160 \text { lt family. }\end{array}$ \\
\hline 6 & Primary school & 40 & 5 & $58-60$ & Teacher: 100 lt. \\
\hline 7 & JSS & 50 & 5 & $58-61$ & Teacher: 100 lt. \\
\hline 8 & SLTA and higher & 80 & 6 & & $\begin{array}{l}\text { Teacher / Lecturer: } 100 \\
\text { lt. }\end{array}$ \\
\hline 9 & Shophouse & $100-200$ & 8 & & Its occupants are $160 \mathrm{lt}$. \\
\hline 10 & Office building & 100 & 8 & $60-70$ & Every employee \\
\hline 11 & $\begin{array}{l}\text { Department Store } \\
\text { (convenience store) }\end{array}$ & 3 & 7 & $55-60$ & $\begin{array}{l}\text { Water usage is only for } \\
\text { latrines, not including } \\
\text { the restaurant section }\end{array}$ \\
\hline 12 & Factory / Industry & $\begin{array}{l}\text { Male laborers: } \\
60 \text { Women: } 100\end{array}$ & 8 & & $\begin{array}{l}\text { Individual each turn (if } \\
\text { you work more than } 8 \\
\text { hours) }\end{array}$ \\
\hline 13 & Station / Terminal & 3 & 15 & & $\begin{array}{l}\text { Each passenger } \\
\text { (arriving or departing) }\end{array}$ \\
\hline 14 & Restaurant & 30 & 5 & & For occupants 160 lt. \\
\hline 15 & Public restaurant & 15 & 7 & & $\begin{array}{l}\text { For occupants } 160 \mathrm{lt} \text {; } \\
\text { waiter: } 100 ; 70 \% \text { of } \\
\text { guests need } 15 \mathrm{lt} / \text { org } \\
\text { for latrines, hand } \\
\text { washing etc. }\end{array}$ \\
\hline 16 & The theater & 30 & 5 & $53-55$ & $\begin{array}{l}\text { If used day and night, } \\
\text { the water usage is } \\
\text { calculated per viewer } \\
\text { the hours of water usage } \\
\text { in the table are for one } \\
\text { show }\end{array}$ \\
\hline 17 & Movie theater & 10 & 3 & & $\begin{array}{l}\text { If used day and night, } \\
\text { the water usage is } \\
\text { calculated per viewer } \\
\text { the hours of water usage } \\
\text { in the table are for one } \\
\text { show }\end{array}$ \\
\hline 18 & Retail store & 40 & 6 & & $\begin{array}{l}\text { Large traders } 30 \text { lt / } \\
\text { guest, } 150 \mathrm{lt} / \text { staff or } 5 \\
\text { lt / day per m3 of floor } \\
\text { area }\end{array}$ \\
\hline 19 & Hotel / Lodging & $250-300$ & 10 & & $\begin{array}{l}\text { For each guest, for staff } \\
120-150 \mathrm{lt} \text {, lodging is } \\
200 \mathrm{lt}\end{array}$ \\
\hline
\end{tabular}




\begin{tabular}{lllll}
\hline 20 & Worship building & 10 & 2 & $\begin{array}{l}\text { Based on the number of } \\
\text { worshipers per day }\end{array}$ \\
21 & Library & 25 & 6 & $\begin{array}{l}\text { For every reader who } \\
\text { lives }\end{array}$ \\
22. & Bar & 30 & 6 & Every guest \\
23. & Social gathering & 30 & & Every guest \\
24 & Night dark & $120-350$ & & Every seat \\
25 & Clubhouse & $150-200$ & & Every guest \\
26. & Laboratory & $100-200$ & 8 & Every staff \\
\hline
\end{tabular}

Sources: Soufyan M. Noerbambang and Takeo Morimura, 1993: 48

Green buiding provides a final advantage that is not presented by conventional buildings. These benefits include energy and water savings, waste reduction, as well as lower personal and maintenance costs. Greenship rating system is a tool for building industry players, both entrepreneurs, engineers and other actors in implementing best practices and achieving measurable standards that can be understood by the general public, especially tenants and building users. A building will be judged by the Greenship by a Professional Greenship (GP). With this appraisal system, each building that proclaims itself as a Green Building will be certified based on the standard criteria contained in the appraisal system, which is grouped into six categories, namely:

1. Appropriate Site Development (Right Cave Land)

2. Energy Efficiency and Conservation

3. Water Conservation

4. Material Resources and Cycle

5. Indoor Air Health and Comfort (Air Quality and Room Comfort)

6. Building Environmantel Management (BEM)

\section{Method}

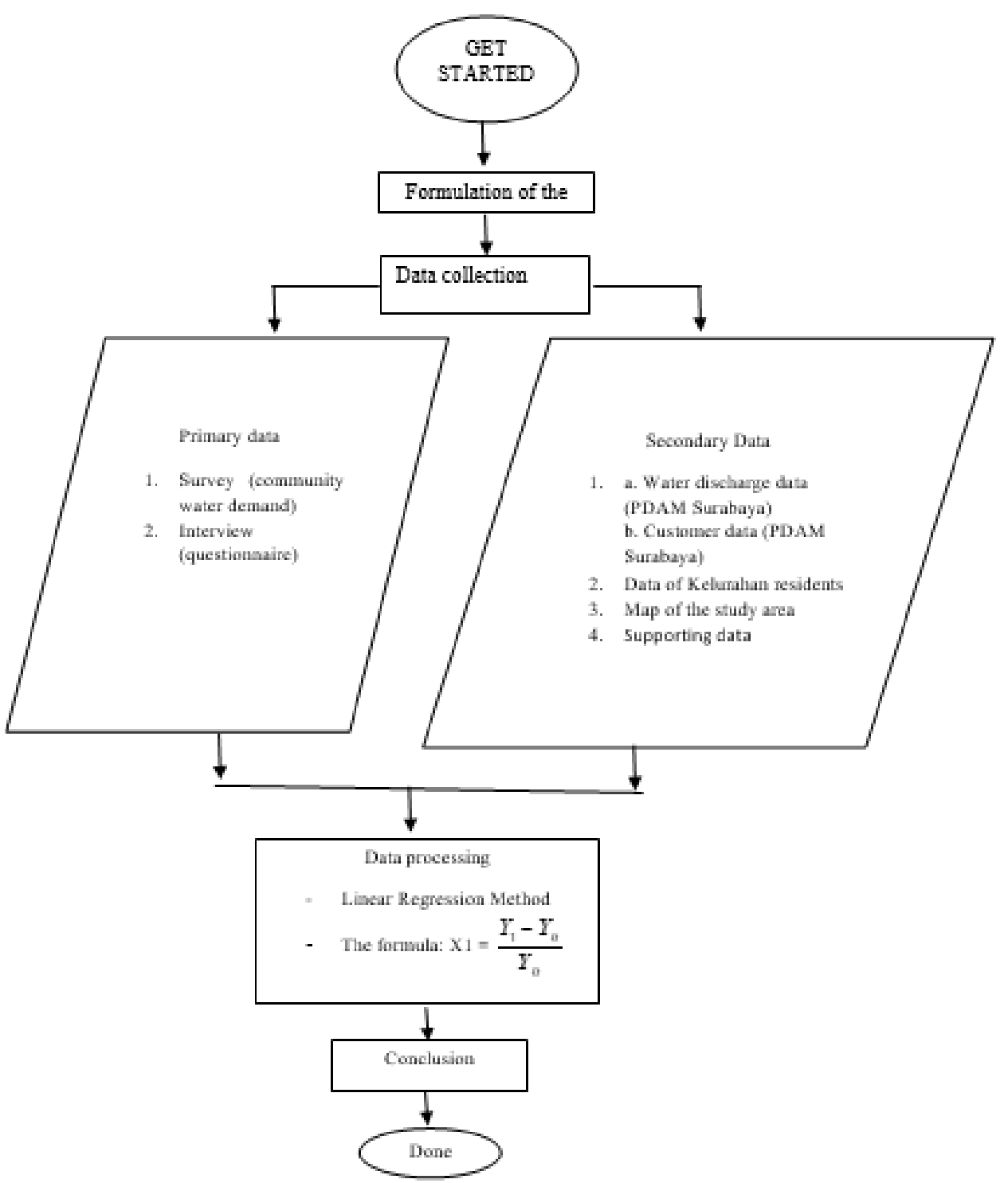

Fig 1. Research Flow Chart 


\section{Results and Discussion}

Table 2. Population Data of Tambak Wedi Village for the past 5 years

\begin{tabular}{ccc}
\hline No & Year & amount \\
\hline 1 & 2015 & 14,550 \\
2 & 2016 & 15,194 \\
3 & 2017 & 16244 \\
4 & 2018 & 17,192 \\
5 & 2019 & 17,754 \\
\hline
\end{tabular}

Source: [5]

Table 3. PDAM Pipe Capacity Data Available

\begin{tabular}{ccc}
\hline$\varnothing$ pipe & Network Pipe Diameter & Discharge (liter / sec) \\
\hline 1 & $\varnothing 110$ mm pipe & 15 \\
2 & $\emptyset 200$ mm pipe & 27 \\
3 & $\varnothing 300$ mm pipe & 41 \\
\hline & Amount & 83 \\
\hline
\end{tabular}

Source: [6]

Population Prediction

Estimated population of Tambak Wedi Village are analyzed using the Linear Regression method with data on population obtained from the Tambak Wedi Kelurahan Office from 2015 to 2019 with predictions until 2029. With the formula:

$$
\begin{aligned}
& \mathrm{X}_{1}=\frac{Y_{1}-Y_{0}}{Y_{\mathrm{o}}} \\
& \mathrm{X}_{5}=\frac{Y_{5}-Y_{4}}{Y_{4}}
\end{aligned}
$$

$$
\mathrm{Y}=\text { Total Population }
$$

Table 4. Linear Regression Methods

\begin{tabular}{cccccccc}
\hline $\mathrm{n}$ & $\mathrm{X}$ & $\mathrm{Y}$ & $\mathrm{R}^{2}$ & $\begin{array}{c}\text { Pers. } \\
\text { Regression }\end{array}$ & $\mathrm{i}$ & i mean & $\mathrm{i}(\%)$ \\
\hline 1 & 2015 & 14550 & .9861 & 14562 & 0 & 0.051 & 5 \\
2 & 2016 & 15194 & & 15402,6 & 0.055 & & \\
3 & 2017 & 16524 & & 16243,2 & 0.052 & \\
4 & 2018 & 17192 & & 17083,8 & 0.049 & \\
5 & 2019 & 17754 & 17924,4 & 0.047 & \\
& & & & .202 & \\
6 & 2020 & & 18765 & & \\
7 & 2021 & & 19605,6 & & \\
8 & 2022 & & 20446.2 & & \\
9 & 2023 & & 21286.8 & & \\
10 & 2024 & & 22127.4 & & \\
11 & 2025 & & 22968 & & \\
12 & 2026 & & 23808,6 & & \\
13 & 2027 & & 24649.2 & & \\
14 & 2028 & & & \\
15 & 2029 & & 25489,8 & & \\
\hline
\end{tabular}




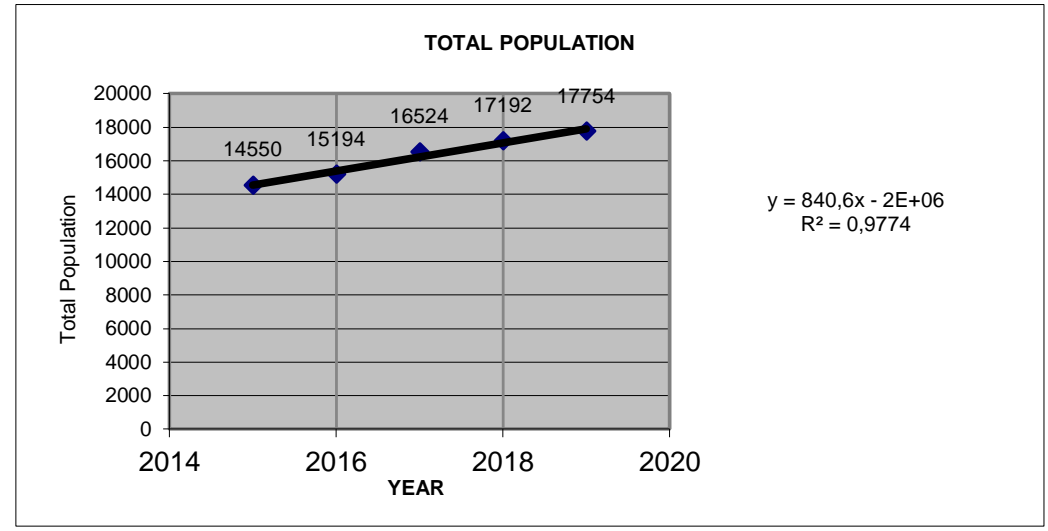

Fig 2. Total Population

The predicted increase in PDAM customers is calculated by the Linear Regression method for each type of customer, from 2015 to 2019 is $455 \mathrm{SR}$, the following results are obtained:

Table 5. needs for clean water in 2019

\begin{tabular}{|c|c|c|}
\hline Customer Group Name & Volume & Unit \\
\hline 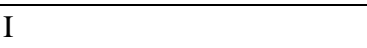 & .150 & $\mathrm{~m}^{3} /$ hour \\
\hline II (2A1) & 4,756 & $\mathrm{~m}^{3} /$ hour \\
\hline III (2A2) & 0.019 & $\mathrm{~m}^{3} /$ hour \\
\hline III (2B) & .108 & $\mathrm{~m}^{3} /$ hour \\
\hline IV (3A) & 10,625 & $\mathrm{~m}^{3} /$ hour \\
\hline $\mathrm{V}(3 \mathrm{~B} 1)$ & 11,200 & $\mathrm{~m}^{3} /$ hour \\
\hline VI (3C1) & 6,250 & $\mathrm{~m}^{3} /$ hour \\
\hline VI (3C2) & 0.833 & $\mathrm{~m}^{3} /$ hour \\
\hline VII (4A) & 86,166 & $\mathrm{~m}^{3} /$ hour \\
\hline VIII (4B1) & 0.066 & $\mathrm{~m}^{3} /$ hour \\
\hline VIII (4B2) & 64,160 & $\mathrm{~m}^{3} /$ hour \\
\hline IX (4C) & 5,000 & $\mathrm{~m}^{3} /$ hour \\
\hline $\mathrm{X}(4 \mathrm{D})$ & 14,660 & $\mathrm{~m}^{3} /$ hour \\
\hline amount & 203,993 & $\mathrm{~m}^{3} /$ hour \\
\hline
\end{tabular}

From the above table, the amount of clean water needed in 2019 or before the construction of Grand Sagara West Surabaya Hotel is obtained is $203.9927 \mathrm{~m}^{3}$ / hour or equal to $0.0566 \mathrm{~m}^{3} / \mathrm{second}$. For the water needs of Grand Sagara West Surabaya Hotel in the operation phase, it is described in the table below.

Table 6. Hotel Water Needs

\begin{tabular}{|c|c|c|}
\hline User & Volume & Unit \\
\hline Occupant & 31,890 & $\mathrm{~m}^{3} /$ hour \\
\hline Employee & 0.750 & $\mathrm{~m}^{3} /$ hour \\
\hline Canteen & .150 & $\mathrm{~m}^{3} /$ hour \\
\hline Musolah & 0.075 & $\mathrm{~m}^{3} /$ hour \\
\hline RTH & .161 & $\mathrm{~m}^{3} /$ hour \\
\hline Swimming pool & 1,210 & $\mathrm{~m}^{3} /$ hour \\
\hline amount & 34,236 & $\mathrm{~m}^{3} /$ hour \\
\hline
\end{tabular}

So from the table above, the amount of clean water needs of Grand Sagara West Surabaya Hotel is $34,236 \mathrm{~m}^{3} /$ hour or equal to 0,00951 $\mathrm{m}^{3} / \mathrm{sec}$. The predicted clean water needs of Tambak Wedi Village in 2029 are 757 SR, consisting of 10 customer groups.

Table 7. needs for clean water in 2029

\begin{tabular}{lrl}
\hline \multicolumn{1}{c}{ Customer Group Name } & Volume & Unit \\
\hline I & 0.275 & $\mathrm{~m}^{3} /$ hour \\
II (2A1) & 9,650 & $\mathrm{~m}^{3} /$ hour \\
III (2A2) & 0.056 & $\mathrm{~m}^{3} /$ hour \\
III (2B) & 0.430 & $\mathrm{~m}^{3} /$ hour \\
IV (3A) & 15,790 & $\mathrm{~m}^{3} /$ hour \\
V (3B1) & 25,200 & $\mathrm{~m}^{3} /$ hour \\
VI (3C1) & 12,500 & $\mathrm{~m}^{3} /$ hour \\
VI (3C2) & 2,910 & $\mathrm{~m}^{3} /$ hour \\
\hline
\end{tabular}




\begin{tabular}{|c|c|c|}
\hline VII (4A) & 148,500 & $\mathrm{~m}^{3} /$ hour \\
\hline VIII (4B1) & .166 & $\mathrm{~m}^{3} /$ hour \\
\hline VIII (4B2) & 120,166 & $\mathrm{~m}^{3} /$ hour \\
\hline IX (4C) & 8,330 & $\mathrm{~m}^{3} /$ hour \\
\hline$X(4 D)$ & 24,330 & $\mathrm{~m}^{3} /$ hour \\
\hline amount & 368,303 & $\mathrm{~m}^{3} /$ hour \\
\hline
\end{tabular}

From the above table, the amount of clean water needed in 2019 or before the construction of Grand Sagara West Surabaya Hotel is $368.3032 \mathrm{~m}^{3}$ / hour or equal to $0.1023 \mathrm{~m}^{3}$ / second. The PDAM Surabaya pipeline network data in the Tambak Wedi Kelurahan is $110 \mathrm{~mm}$, $200 \mathrm{~mm}$ and $300 \mathrm{~mm}$ in diameter. Existing water discharge at $\varnothing 110 \mathrm{~mm}$ is $15 \mathrm{ltr} / \mathrm{sec}, \varnothing 200 \mathrm{~mm}$ pipe is $27 \mathrm{ltr} / \mathrm{sec}$ and $\varnothing 300 \mathrm{~mm}$ pipe is $41 \mathrm{ltr} / \mathrm{sec}$. So, the total water debit of PDAM in Surabaya in Tambak Wedi Village is 83 liters / second or equal to $0.083 \mathrm{~m}^{3} / \mathrm{sec}$.

\section{Conclusion}

From all of the calculations, the data processing, and the discussion, the following conclusions were drawn:

1. The largest free speed $\left(\mathrm{S}_{\mathrm{ff}}\right)$ was on the fragment of road before narrowing and decreased on the fragment of road during narrowing and increased one more time on the fragment of road after narrowing. The biggest density $\left(D_{j}\right)$ was on the fragment of road during narrowing and then decreased on the fragment of road after narrowing. The highest maximum volume $(\mathrm{Vm})$ was found on the fragment of road after narrowing.

2. There was a significant correlation $\left(\mathrm{R}^{2}>0.5\right)$ between flow, speed, and density.

3. Based on the survey conducted on Wednesday and Saturday, there were shock waves as follows: on Wednesday at 06:00 to 09:00 (the backward forming shock wave was $0.51992 \mathrm{~km} / \mathrm{hour}$, the forward recovery shock wave was $0.10742 \mathrm{~km} / \mathrm{hour}$ ), 16:00 - 18:00 (the backward forming shock wave was $0.30675 \mathrm{~km} /$ hour, the forward recovery shock wave was $0.59993 \mathrm{~km} /$ hour). Moreover, on Saturday 07:00 - 09:00 (the backward forming shock wave was $0.51601 \mathrm{~km} /$ hour, and the forward recovery shock wave was $0.06270 \mathrm{~km} / \mathrm{hour}$ ), 16:00 - 18:00 (the backward forming shock wave was $0.25655 \mathrm{~km} /$ hour, the forward recovery shock wave was $0.92341 \mathrm{~km} / \mathrm{hour}$ ).

\section{References}

[1] S. Tyagi, B. Sharma, P. Singh, and R. Dobhal, "Water Quality Assessment in Terms of Water Quality Index," Am. J. Water Resour., vol. 1, no. 3, 2020, doi: 10.12691/ajwr-1-3-3.

[2] L. E. Armstrong and E. C. Johnson, "Water intake, water balance, and the elusive daily water requirement," Nutrients, vol. 10, no. 12. 2018, doi: 10.3390/nu10121928.

[3] S. Yudo and N. I. Said, "Kondisi Kualitas Air Sungai Surabaya Studi Kasus: Peningkatan Kualitas Air Baku PDAM Surabaya," J. Teknol. Lingkung., vol. 20, no. 1, 2019, doi: 10.29122/jtl.v20i1.2547.

[4] N. SUDAPET, “Analisis Service Quality terhadap Kepuasan Pelanggan pada PDAM Kota Surabaya,” BISMA (Bisnis dan Manajemen), vol. 2, no. 1, 2018, doi: 10.26740/bisma.v2n1.p42-47.

[5] E. Suprayitno and N. Huzaimah, "PENDAMPINGAN LANSIA DALAM PENCEGAHAN KOMPLIKASI HIPERTENSI," SELAPARANG J. Pengabdi. Masy. Berkemajuan, 2020, doi: 10.31764/jpmb.v4i1.3001.

[6] E. M. Ulfah and T. A. Auliandri, "Analisis Kualitas Distribusi Air Menggunakan Metode Six Sigma DMAIC Pada Pdam Surya Sembada Kota Surabaya," INOBIS J. Inov. Bisnis dan Manaj. Indones., vol. 2, no. 3, 2019, doi: 10.31842/jurnal-inobis.v2i3.93. 